\title{
CRITERIA FOR CONSULTANT AND ADVISOR IN THE BRAZILIAN POSTGRADUATE SYSTEM
}

\author{
Critérios para avaliar consultoria e assessoria na pós-graduação stricto sensu
}

Andy Petroianu

\section{A BSTRACT}

\begin{abstract}
Objective: To review the rules, resolutions and existing documents relating to consultant and advisor to better target the actions of those who exercise these roles. Methods: The following documents were consulted: Statute of CAPES, through Decree No. 7692 of March 2, 2012; Ordinance No. 47 of 17/10/1995; Opinion 9771965 Newton Sucupira; Area Document of Medicine III; Interministerial Ordinance 251 of 2012, based on Decree No. 7642 of 2011 of the Ministry of Science and Technology; CAPES Regiment. Results: The Brazilian Postgraduate system is divided in two different fields, according to its aspects: the "lato sensu" postgraduate, defined as all professional studies performed after the high school graduation; and the "stricto sensu" postgraduate that includes the master degree and the doctorate, both of them different from what is known as MSc or MS and PhD. The Brazilian doctorate is recognized as academic because its purposes include to improve the scientific and the teaching levels of university docents. The master degree has two different objectives one is to be academic and similar to the doctorate; the other is to upgrade professionals to a higher level than specialist or MBA and is denominated professional master degree. The master degrees and the doctorate are designated as courses and may be put together in a structure known as stricto sensu postgraduate program. The complexity of these courses and programs in all the areas of the superior human knowledge requires a large number of professional directly involved with this system and other professionals that attend them, called consultants and advisors. The consultants are counselors, and the advisors are assistants, both of them legally established with the incumbency to aid the postgraduate staff in all their duties. Conclusion: Nothing prevents a person from being a consultant on the situation and advisor on another, even in the same institution. Have knowledge about what being a consultant and advisor is required to exercise the function within the limits and dimension that the wingspan of the professional allows.
\end{abstract}

Key Words - Consultants, Directive Counseling, Health Postgraduate Programs.

\section{INTRODUCTION}

Iistorically, Professor Newton Sucupira, in front of a committee of professors of high level, created the Postgraduate strict sensu in Brazil, through its Opinion 977 of 1965. In this document, the postgraduate was divided into Master and Doctorate. The Doctorate was named Academic, having the responsibility to train professionals and researchers of higher education to the Doctor degree. But the Master, that graduates until the Master's degree, was divided into Academic, with the same objectives of Doctoral, and Professional, to reach not university connected professionals, but who wish to qualify above specialization ${ }^{1,2,3}$.

Until the 1990s, there was no interest in the Professional Master degree. However, Brazilian social changes had among its consequences the need for graduate non-university business professionals, and thus the Professional Master was reactivated by Ordinance No. 47 of 17/10/1995. The pent-up demand for professionals with graduation higher than specialization and Technological Master (MBA - Master of Business Administration) stimulated the opening Professional Master in all areas of knowledge in number each time bigger $1,2,3,4,5$. In that regard, it is worth noting the essence of the MBA that "no one seeks a professional to speak about a problem (characteristic of most of the studies of the Academic Postgraduate), but to fix it (final product of Professional Master)"1,3.

The organization of postgraduate studies has become complex and the Master's and Doctoral programs were gathered in. Initially, these programs were related to restricted areas of knowledge, but progressively greater interrelationship of science has expanded and integrated from its various origins $5,6,7,8$. The management of these programs requires diverse multidisciplinary structure in all levels, consisting of nuclear team associated with consultants and advisors.

The objective of this study was to review the rules, resolutions and existing documents on the subject to better guide the actions of those who exercise these roles.

\section{METHOD}

To prepare this article the following documents were con- sulted: Statute of CAPES, through Decree No. 7692 of March 2, 2012; Ordinance No. 47 of 17/10/1995; Opinion 9771965 Newton Sucupira; Area Document of Medicine III; Interministerial Ordinance 251 of 2012, based on Decree No. 7642 of 2011 of the Ministry of Science and Technology; CAPES Regiment. These documents were analyzed only on topics related to consultancy and advice services for stricto sensu postgraduate programs.

\section{RESULTS}

Consultancy

Consultant, Latin term to designate the counselor, refers to a person considered wise and enough culture to contribute institutionally in problem solving. Consultants are independent persons, not affiliated with the person who invites him and, in that sense, it is expected of them neutrality in the execution of the requested tasks in which it is assumed cultural, scientific and humanistic dominance.

Consultancy is regulated by the Statute of CAPES, through Decree No. 7692 of 02 March 2012. In that document, it is worth mentioning the following items of interest to the community linked to post-graduate programs ${ }^{9,10}$ :

Article 1 - The action of scientific consultants from CAPES does not establish an employment contract and covers the upper boards, commissions, committees and working groups as well as individual participation, as ad hoc call. Article 2 - The coordination of the activities of consultants is made by a consultant called Area Coordinator, except for lines of action and programs that have special committees themselves.

Article 4 - The Scientific Consultant shall comply with the legislation and:

I - to conduct themselves by the dictates of ethics;

II - rule with autonomy and independence;

III - ensure the quality, consistency, accuracy and justification of opinions given;

IV - maintain secrecy about the project proposals entrusted to them and that becomes aware.

The characteristics of the consultant mentioned specifically for the Professional Master, apply for postgraduate strictly in general and $\operatorname{are}^{9,10:}$ 1) have a doctorate in the area of operation as a consultant; 2 ) have five years of experience in coordinating 
activities, training of high level professionals and publication of scientific articles in their area; 3) be linked to teaching and research institution; 4) be able to draw up proposals to generate a product.

On the document of Medicine III, the advisor is valued as an important attribute of the Faculty; the Proposal of Graduate Programs in its item 2.1, in which are highlighted the functions of advisors, says ${ }^{8,11,12: 1)}$ ) visiting person in higher institutions, to joint scientific research; 2) technical and scientific advisor; 3 ) editor or member of the editorial board of scientific journals; 4) reviewer and consultant of scientific journals.

In the same document, no grading or note exist in order to quantify objectively the evaluation of programs, in all aspects, evenly. Considering the Qualis evaluation, which is attributed to scientific journals, would be interesting, at first and until specific gradation is created, to grade by "similarity" quantifying the values assigned to each consultant, according to the importance of his job ${ }^{13,14}$ (Table 1).

TABLE 1 - Proposal to quantify the values assigned to each consultant

\begin{tabular}{|l|l|}
\hline International official organ & $3 \mathrm{~A} 1$ / year \\
\hline No official international organ & $2 \mathrm{~A} 1$ / year \\
\hline National official organ & $2 \mathrm{~A} 1$ / year \\
\hline No official national organ & $1 \mathrm{~A} 1 /$ year \\
\hline Regional official organ & $1 \mathrm{~B} 1 /$ year \\
\hline No regional official organ & $1 \mathrm{~B} 2$ / year \\
\hline ad hoc internacional & $1 \mathrm{~B} 3 /$ year \\
\hline ad hoc national & $1 \mathrm{~B} 4$ / year \\
\hline
\end{tabular}

\section{Advisory}

The term advisor also comes from the Latin "assessors" and means helper. So his role differs from that played by the consultant, for being linked to the applicant and indicates functional dependency relationship. Within the area of knowledge, the assessor is considered the requesting agent and may eventually replace or represent him. The applicant is not necessarily a person, but may be a department and to an institution. CAPES has great body of advisors distributed in their fields, who are professionals belonging to the institution and not invited, as consultants are.

Advisory is also normalized by specific legislation. While not belonging to the CAPES Regiment, the Interministerial Ordinance 251 of 2012, based on Decree No. 7642 of 2011 of the Ministry of Science and Technology, is applicable to all public advisory. In its Article 2, which deals with the Advisory Committee, are assigned to the following functions ${ }^{15,16}$ :
IV. pronounce on the actions taken to meet the goals; $\checkmark$. analyze and forward relevant issues;

$\mathrm{VI}$. monitor and review the implementation of goals; VII. disseminate results.

Herself CAPES determined to her advisors the following provisions: 1) examine proposals for the improvement of high-level activities in the system; 2) support the preparation of public notice and setting standards for the programs; 3 ) advise on matters within its area of expertise; 4) prepare list of consultants for analysis of merit of the submitted proposals; 5) prioritize the submitted proposals; 6) monitor the implementation and the development of proposals; and 7) represent the CAPES in events linked to their area of expertise.

In the Area Document Medicine III, the advisory performance by the Faculty is mentioned in the Proposal of Postgraduate Programs in item 5.2 as part of the Social Inclusion, highlighted with less value than consulting. Thus, similarly to what was presented for the consulting, to quantify the value of advisory it can be ranked according to importance of where the assessor acted (Table 2).

TABLE 2 - Proposal to quantify the value of advisory for postgraduate based on the importance of where the assessor acted

\begin{tabular}{|l|l|}
\hline International official organ & 1 B1 / year \\
\hline Unofficial international organ & $1 \mathrm{~B} 2 /$ year \\
\hline National official organ & $1 \mathrm{~B} 2$ / year \\
\hline No official national organ & $1 \mathrm{~B} 3 /$ year \\
\hline Regional official organ & $1 \mathrm{~B} 4 /$ year \\
\hline No regional official organ & $1 \mathrm{~B} 5 /$ year \\
\hline
\end{tabular}

\section{CONCLUSION}

Nothing prevents a person from being a consultant on the situation and advisor on another, even within the same institution; however, the charges are different in each of these roles. It cannot be considered only the importance for the position, but the way the professional performs the task given to him. Have knowledge about what is being a consultant and advisor is required to exercise the function within the limits of its competence and in the dimension that the professional wingspan allows.

I. propose actions for the proper development;

II. propose targets and performance indicators;

III. propose priority areas for action;

\section{RESUMO}

Objetivo: Revisar as normas, resoluções e documentos vigentes relativos ao tema consultoria e assessoria para melhor orientar as atuações de quem exerce esses papéis. Métodos: Foram consultados os seguintes documentos: Estatuto da CAPES, por meio do Decreto № 7.692, de 02 de março de 2012; Portaria no 47 de 17/10/1995; Parecer 977 de 1965 de Newton Sucupira; Documento de Área da Medicina III; Portaria Interministerial 251 de 2012, com base no Decreto n 7642 de 2011 do Ministério de Ciência e Tecnologia; e Regimento da CAPES. Resultados: O gerenciamento dos programas de pós-graduação stricto sensu requer estrutura multiprofissional diversificada em todos os seus níveis, constituída por corpo próprio da instituição e por componentes agregados, incluindo os consultores e assessores. O consultor é pessoa independente, sem vínculo com quem o convida e, nesse sentido, espera-se dele isenção na execução das tarefas solicitadas, nas quais se pressupõe domínio cultural, científico e humanístico. No Documento de Área da Medicina III, a consultoria é valorizada como atributo importante do Corpo Docente e está mencionada na Proposta dos Programas de Pós-graduação em seu item 2.1. Por outro lado, o assessor está vinculado ao solicitante em relação de dependência funcional. Dentro de sua área do conhecimento, o assessor é considerado adjunto do solicitante e pode substituí-lo ou representá-lo. No Documento de Área da Medicina III, o desempenho de assessoria pelo Corpo Docente está mencionado na Proposta dos Programas de Pós-graduação em seu item 5.2. Ter conhecimento sobre o que significa ser consultor e assessor é necessário para exercer a função dentro dos limites que the compete e na dimensão que a envergadura do profissional permite. Conclusão: Nada impede que uma pessoa seja consultora em situação e assessora em outra, até na mesma instituição. Ter conhecimento sobre o que significa ser consultor e assessor é necessário para poder exercer a função dentro dos limites que lhe compete e na dimensão que a envergadura do profissional permite.

Descritores - Consultores. Aconselhamento diretivo. Programas de Pós-Graduação em Saúde. 


\section{REFERENCES}

1. Petroianu A. Mestrado profissionalizante em cirurgia. Rev Col Bras Cir 2008; 35: 2-4.

2. Petroianu A. A pesquisa em Medicina. Medicina 1992; 25: 327-9.

3. Petroianu A. Considerações sobre a pós-graduação stricto sensu em Medicina. Santa Casa Notícias 1997; 75: 6-8.

4. Petroianu A. Aspectos éticos da pesquisa em cirurgia. Bol Col Bras Cir 2001; 32: 45-8.

5. Petroianu A. Avaliação da quantidade da produção científica brasileira. Rev Col Bras Cir 2012; 39: 169-70.

6. Petroianu A. A pesquisa em Medicina na graduação e pós-graduação. Bioética 2003; 11: 153-60.

7. Araújo RS, Brito FN, Chaves Y, Veiga DF, Ferreira LM. Surgical research in the north and northeast of Brazil. Acta Cir Bras 2013; 28: 467-73.

8. Oliveira Filho RS, Hochman B, Nahas FX, Ferreira LM. Fomento à publicação científica e proteção do conhecimento científico Acta Cir Bras 2005; 20 Supl 2: 35-9.

9. http://www.capes.gov.br/busca?searchword=consultoria\&searchphrase=all

10. http://www.capes.gov.br/busca?searchword=consultor\&searchphrase=all
11. Hochman B, Locali RF, Oliveira Filho RS, Oliveira RL, Goldenberg $S$, Ferreira LM. Padronização da terminologia dos centros médicos universitários e de pesquisa biomédica, no idioma inglês, para envio de artigo de revista. Acta Cir Bras 2006; 21: 271-4.

12. Pizzani L, Lopes JF, Manzini MG, Martinez CM. Bibliometric analysis of theses and dissertations on prematurity in the CAPES database. J Pediatr 2012; 88:479-82.

13. Petroianu A. Publicação do trabalho científico. Ciência e Cultura 1985; 37: 410-3.

14. Petroianu A. Autoria de um trabalho científico. Rev Assoc Med Bras 2002; 48: 60-5.

15. http://www.capes.gov.br/busca?searchword=assessoria\&searchphrase=all

16. http://www.capes.gov.br/busca?searchword=assessor\&searchphrase=all

Received on: 19/02/2015

Accepted for publication: 12/09/2015

Conflict of interest: none

Source of funding: none

Address for correspondence:

Andy Petroianu

petroian@gmail.com 